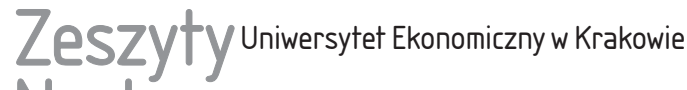 Naukowe
}

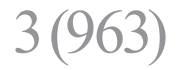

ISSN 1898-6447

Zesz. Nauk. UEK, 2017; 3(963): 23-37

DOI: 10.15678/ZNUEK.2017.0963.0302

\section{Andrzej Słabón}

\section{Rozwój miasta - społeczna dynamika przekształceń*}

\section{Streszczenie}

Rozwój miasta w artykule rozumiany jest jako ciąg wzajemnie ze sobą powiązanych zmian zachodzących w różnych sferach życia mieszkańców. Interakcje między różnymi podmiotami aktywnymi na obszarze miasta są istotnym elementem warunkującym przemiany zachodzące w tej sferze. Za szczególnie doniosły uznano związek między zmianami społecznymi a codziennymi zachowaniami mieszkańców. Zachowania te są kształtowane w znacznym stopniu przez regulacje normatywne. Nadmiar tych regulacji prowadzi do procesów pacyfikacji, które wywołują reakcje kompensacyjne. Dynamika przekształceń miasta w sferze społecznej kształtowana jest w znacznej mierze przez związek procesów pacyfikacji oraz kompensacji.

Słowa kluczowe: rozwój miasta, zachowania masowe, zmiana społeczna, pacyfikacja, kompensacje.

Klasyfikacja JEL: R11.

\section{Wprowadzenie}

Rozwój miasta ujmować można jako ciąg powiązanych z sobą zmian zachodzących w różnych sferach życia obywateli. Taki sposób rozumienia pojęcia rozwoju pozwala uniknąć coraz częściej formułowanych zastrzeżeń dotyczących

Andrzej Słaboń, Uniwersytet Ekonomiczny w Krakowie, Wydział Gospodarki i Administracji Publicznej, Kateda Socjologii, ul. Rakowicka 27,31-510 Kraków, e-mail: slabona@uek.krakow.pl

* Artykuł powstał w ramach badań statutowych Katedry Socjologii finansowanych ze środków własnych przez Uniwersytet Ekonomiczny w Krakowie. 
zasadności jego stosowania. Zastrzeżenia budzą po pierwsze niepowodzenia programów pomocy w rozwoju krajom biednym, w tym kontekście mówi się o „końcu rozwoju” [Hart i Padayachee 2011 s. 61]; po drugie - wyrastająca z postmodernizmu krytyka teorii modernizacji i przyjmowanych w jej obrębie założeń. W pierwszym przypadku termin „rozwój” odnoszony jest do programów pomocy, a niepowodzenie polityki w takim zakresie nie musi oznaczać odrzucenia zasadności posługiwania się tym pojęciem w sferze nauki. Drugi typ zastrzeżeń dotyczy sposobu ujmowania zmian i nadawania im dodatkowego znaczenia, prowadzącego do prób rozpoznania sensu procesu historycznego. Zagadnienie rozwoju, w tym także rozwoju miast, obejmuje próbę rozpoznania zachodzących kierunków zmian, a także odpowiedzi na pytanie o czynniki warunkujące rozwój. Taka wiedza pozwala oddziaływać na tempo zachodzących zmian i sterować jego przebiegiem, jest zatem niezwykle użyteczna.

W niniejszym artykule podejmuje się próbę wypracowania stanowiska w zakresie społecznej dynamiki przekształceń, nie rezygnując jednak z posługiwania się terminem „rozwój”. Wydaje się to tym bardziej zasadne, że w obrębie socjologii historycznej powstają nowe specjalizacje mające „rozwój” w swej nazwie [Orren i Skowronek 2004]. Jednakże redukowanie rozwoju do prostych determinizmów monokauzalnych, a także utożsamianie go z „postępem” wydaje się zbyt daleko idącym uproszczeniem. Przyjmowany ideał wiedzy, sytuujący się w obrębie założeń modernistycznych, w istotny sposób wpływa na to, jaki rodzaj wiedzy uznaje się za „właściwy” i poniekąd przesądza w sprawie uzyskiwanych rezultatów poznawczych [Amsterdamski 1983]. Dążenie do wiedzy pozwalającej na sterowanie procesami rozwoju mieści się w wąsko rozumianym nurcie racjonalności instrumentalnej. Próby rozpoznania kierunków zachodzących zmian wpisują się najczęściej w nurt neoewolucjonistyczny i sprowadzają się zwykle do sygnalizowania coraz to nowych przejść od jednego typu społeczeństwa do innego typu. Prace wielu autorów koncentrują się na wynajdywaniu coraz nowszych „typów społeczeństw” lub „typów miast”, które określać mają kierunki zachodzących zmian. Koncepcje te stają się zwykle przedmiotem ożywionej debaty i przyczyniają się do poszerzenia przyjętego w naukach społecznych spojrzenia na rozwój. $Z$ uwagi na wielość tego typu ujęć warto spróbować wyjść poza ten schemat analizy. Oczywiście łatwiej jest krytykować istniejące koncepcje niż proponować nowe podejście, szczególnie że trudno jest wykroczyć poza uwarunkowania kształtujące własne myślenie i postrzeganie.

W przyjętym tutaj kierunku analizy próbuje się te różne ujęcia zintegrować i zwrócić uwagę na pewne aspekty rozwoju miast, które nie są szeroko eksponowane w literaturze przedmiotu. Analizując problem rozwoju miast, wskazuje się zwykle całą gamę czynników wpływających na ten rozwój. Poszczególni autorzy koncentrują swoją uwagę na wybranych uwarunkowaniach, charakterystycznych 
dla poszczególnych typów nauk zajmujących się tym problemem, a więc na uwarunkowaniach ekonomicznych, społecznych, geograficznych, politologicznych itp. Wielość czynników kształtujących rozwój miast wymaga ,uporządkowania", a więc wzajemnego powiązania różnych wskazywanych aspektów. Konieczne jest nie tylko przezwyciężanie barier między poszczególnymi dyscyplinami naukowymi, ale także analiza wzajemnych powiązań między różnymi czynnikami ujmowanymi w odmiennych kontekstach. Związki występujące między poszczególnymi czynnikami lub grupami zmiennych stwarzają szansę na rozpoznanie swoistej „logiki rozwoju” ukształtowanej w badanym obszarze. Nie chodzi tu o analizy w stylu heglowskiej filozofii dziejów. Warto jednak zwrócić uwagę, że sam sposób ujmowania miasta (jego „natury” lub ,istoty”) kształtuje tę rzeczywistość miejską. Sposoby myślenia o mieście odwołują się do przyjmowanych założeń, sposobów wartościowania i definiowania miasta, a przez to wpływają na zachowania i podejmowane decyzje, które z kolei kształtują tę rzeczywistość i zwrotnie podtrzymują przyjmowany obraz miasta lub go modyfikują.

Wspomniane logiki rozwojowe miasta zawierają w sobie sposoby myślenia i wartościowania charakterystyczne dla różnych grup mieszkańców oraz władz i innych podmiotów, przekładając się na ich sposoby działania. Sytuacja aktywnych podmiotów jest taka, że ich działania (w tym także wybór celów i sposobów realizacji) jest warunkowany sposobem postrzegania istniejącej sytuacji, a zarazem podejmowane działania tę sytuację i sposób postrzegania zmieniają. Działanie i poznanie są w tym przypadku wzajemnie powiązane. $\mathrm{W}$ tę sytuację wpisują się także sposoby waloryzowania i oceny zachodzących przekształceń (lub ich braku). Na rozwój miasta warto więc spojrzeć z perspektywy zmiany zachowań zbiorowych. To podejście nie wyczerpuje możliwych perspektyw poznawczych, ale wydaje się szczególnie doniosłe. Zachowania mieszkańców mogą przyczyniać się do rozwoju miasta lub do stagnacji. Często podejmowane są różne działania mające na celu kształtowanie pożądanych zachowań, warto tym procesom przyjrzeć się dokładniej. Z uwagi na to, że w praktyce najbardziej rozpowszechnionym sposobem modelowania pożądanych zachowań społecznych są przepisy prawne warto poświęcić nieco uwagi funkcjonowaniu sfery normatywnej.

\section{Zachowania masowe a rozwój miasta}

Miasto jest bytem niezwykle złożonym i dlatego może być ujmowane $\mathrm{z}$ wielu perspektyw poznawczych. Mówiąc, że jest „,bytem”, już tym samym zakłada się traktowanie miasta jako „przedmiotu” lub „obiektu” na wzór przedmiotów fizycznych. Tymczasem ten aspekt ,przedmiotowy” jest w istocie wtórny, gdyż miasto może być ujmowane jako zespół wielu nakładających się na siebie 
procesów społecznych, zarówno ludzkich działań, jak i procesów zachodzących na poziomie ponadjednostkowym. Miasto w ujęciu Georga Simmla [1975] oraz klasyków Szkoły Chicago to przede wszystkim stan umysłu [Park 1925, Znaniecki 1931], a zatem specyficzny sposób myślenia i odczuwania. Ten aspekt warto brać pod uwagę, próbując badać kwestie dotyczące zmiany i rozwoju miast. Sposób myślenia o mieście przekłada się bowiem na ludzkie zachowania, a te kształtują środowisko i przemiany, jakie w nim zachodzą. Myślenie o mieście przybiera różne formy - składają się nań nie tylko refleksje i odczucia na temat warunków życia w konkretnym mieście, ale także procesy definiowania oraz interpretowania różnych sytuacji i obserwowane praktyki. Sposoby ujmowania miasta przez poszczególne grupy mieszkańców oraz interesariuszy są zazwyczaj zróżnicowane. Te odmienne wizje ścierają się ze sobą i często prowadzą do konfliktów.

Rozwój miasta nie może być postrzegany wyłącznie w kategoriach rozwoju jego substratu materialnego (powstawania nowych budynków, ulic, obiektów użyteczności publicznej, poprawy infrastruktury technicznej itp.), lecz trzeba go ujmować przez pryzmat wzajemnych relacji między różnymi grupami i środowiskami społecznymi występującymi w obrębie miasta. Dynamika tych relacji może być ujmowana w świetle różnych teorii. Najczęściej przyjmowana jest perspektywa teorii konfliktu społecznego, w której akcentuje się różnice interesów między poszczególnymi grupami i walkę o władzę. Ujęcie to widoczne jest w teoriach marksistowskich i neomarksistowskich, a także w ujęciu relacjonistycznym Pierre'a Bourdieu [2009], nurcie interakcjonistycznym [Blumer 2007] lub w teorii reżimów [Sagan 2000, Gerencser i in. 2008]. Miasto jest tu postrzegane jako miejsce walki o wpływy, pozycje, interesy i korzyści poszczególnych grup lub, jak w przypadku nowych ruchów społecznych, walka dotyczy jakiejś „,sprawy” uznawanej za istotną dla ogółu mieszkańców lub środowisk zmarginalizowanych, niezdolnych do samodzielnej walki o własne interesy. Konflikt o władzę w tym ujęciu to walka o zmianę ustanowionych reguł gry.

Głównymi „aktorami” występującymi na scenie miasta są władze, mieszkańcy, przybysze (np. turyści, osoby przebywające w mieście przez krótki czas), przedsiębiorcy i szeroko rozumiana sfera biznesu. Każdy z tych podmiotów jest wewnętrznie zróżnicowany i w jego obrębie także toczą się wzajemne interakcje i gry interesów. W obrębie władz miasta występują różne gremia decyzyjne, gry interesów między poszczególnymi instytucjami sektora publicznego, a także naciski ze strony władz centralnych i wojewódzkich, miast sąsiednich, instytucji unijnych, opinii publicznej, środków masowego przekazu. Mieszkańcy także są wewnętrznie zróżnicowani - niektóre środowiska są mocno zaangażowane w sprawy dotyczące funkcjonowania miasta, inni zachowują się obojętnie; jedni angażują się tylko w sprawy, które dotyczą ich bezpośrednio, inni podejmują działania oddolne na rzecz dobra wspólnego. W tym obszarze działają różne 
stowarzyszenia i organizacje kanalizujące i animujące aktywność obywatelską. Każdy z tych podmiotów może wysuwać pewne roszczenia pod adresem władz oraz innych aktorów sceny miejskiej.

Kwestia rozwoju miast rozpatrywana z perspektywy wzajemnych interakcji zachodzących między poszczególnymi grupami interesariuszy oznacza, że od charakteru wzajemnych relacji zależy w znacznej mierze dynamika zachodzących przekształceń w sferze miejskiej. Na problem ten warto spojrzeć poprzez kształtowanie się zachowań zbiorowych. Rozwój miasta, to z jednej strony działania „odgórne" podejmowane przez władze, z drugiej strony to działania „oddolne”, bardziej lub mniej spontaniczne, różnych grup mieszkańców (lub ich samozwańczych rzeczników). Między tymi dwoma typami działań zachodzą wzajemne oddziaływania. Z perspektywy władz miasta zarówno „nadmiar” aktywności obywatelskiej, jak i jej niedobór stanowią pewną uciążliwość. Z perspektywy mieszkańców brak normatywnych regulacji niektórych obszarów aktywności, jak i ich nadmiar stwarzają sytuacje niepożądane. Postawić można pytanie, jak dochodzi do wypracowania pewnego stanu równowagi sytuującego się między wskazanymi skrajnościami.

Główną rolę odgrywa proces komunikacji między stronami, a także w ich obrębie. Komunikacja ta przybierać może różne formy - od bezpośrednich rozmów, a nawet negocjacji, do „głosowania nogami”, czyli reakcji behawioralnych na istniejące warunki życia w mieście. Decyzje władz będące reakcją na zauważane problemy funkcjonowania miasta, zwłaszcza w odniesieniu do warunków życia jego mieszkańców, kształtują sferę normatywną. Rożnego typu regulacje, zarządzenia, przepisy porządkowe, ograniczenia mające na celu koordynację indywidualnych zachowań obywateli, tworzą dosyć złożony system normatywny ograniczający dowolność zachowań [North 2006]. W niektórych przypadkach mieszkańcy (nie wszyscy, ale pewna ich część lub reprezentanci) a także media domagają się wprowadzenia jakichś regulacji. Niekiedy porządek normatywny kształtuje się spontanicznie; mieszkańcy sami ustalają reguły zachowań w niektórych typach sytuacji. Niejednokrotnie te oddolnie ustanowione zasady są później formalizowane i z fakultatywnych stają się obligatoryjnymi.

Zachowania zbiorowe stają się elementem procesu decyzyjnego nie tylko władz, ale i pozostałych podmiotów występujących na terenie miasta. Istotną rolę odgrywa możliwość przewidywania zachowań społecznych. Każde przedsięwzięcie inwestycyjne, czy to w sferze domeny publicznej, czy w sferze biznesu, wiąże się z przyjęciem pewnych założeń odnoszących się do przewidywanych zachowań różnych grup mieszkańców ujmowanych w kategoriach potencjalnych klientów. Trafność tych przewidywań warunkuje niejednokrotnie pomyślność realizowanego przedsięwzięcia. Problem w takim przypadku polega jednak nie tylko na tym, żeby rozpoznać indywidualne preferencje statystycznej próby 
mieszkańców, bo to jest stosunkowo łatwe, ale na tym, że trzeba antycypować oczekiwania mieszkańców, których oni sami sobie w danym momencie jeszcze nie uświadamiają. Do pewnego stopnia trzeba niektóre potrzeby kreować, co nie zawsze gwarantuje powodzenie takiego przedsięwzięcia.

Można postawić tezę, że bardziej lub mniej dynamiczny rozwój miasta zależy w znacznym stopniu od zdolności kształtowania zachowań zbiorowych jego mieszkańców. Miasta będące skupiskiem wielu tysięcy bądź milionów mieszkańców muszą w jakiś sposób regulować ich zachowania. Pierwszym, podstawowym czynnikiem organizującym zachowania ludzi w mieście jest jego układ przestrzenny - lokalizacja układu osadniczego, miejsc pracy, infrastruktury usług, sieci komunikacyjnych itp. Na te warunki materialne nakładają się wzory i reguły ludzkich zachowań. Ten aspekt wydaje się szczególnie istotny w kontekście dynamiki rozwoju miast, gdyż umożliwia on koordynację indywidualnych działań tysięcy jednostek. $\mathrm{Z}$ drugiej strony, różnego typu innowacje będące często wytworem poszczególnych osób, aby stały się elementem życia społecznego, muszą być przyswojone sobie przez szerokie kręgi społeczne. Od tempa przyswojenia sobie tych innowacji zależy w znacznej mierze dynamika rozwoju. Zachowania masowe często mają charakter krótkotrwały, przybierając formę chwilowej mody lub „kaprysów” społecznych ( $f a d s)$. Niejednokrotnie jednak moda towarzyszy wprowadzaniu do powszechnego użytku nowych urządzeń technicznych, tak było z szybkim rozpowszechnianiem się różnych gadżetów elektronicznych, które stały się trwałym elementem życia codziennego.

Rozwój miast jest ściśle powiązany ze zmianami zachowań masowych jego mieszkańców. Ukształtowane w sposób spontaniczny praktyki i wzory zachowań muszą być niejednokrotnie zmieniane, gdyż ujawniają swój dysfunkcjonalny charakter. Egzemplifikacją tego typu sytuacji są zachowania przyczyniające się do degradacji naturalnego środowiska. Mając na względzie ochronę zasobów Ziemi, wprowadzono obowiązek segregowania odpadów, dzięki opomiarowaniu mieszkań zracjonalizowano zużycie energii oraz wody przez lokatorów. $\mathrm{W}$ ostatnim czasie nasilił się problem zanieczyszczenia powietrza w miastach. Zmiany w tym zakresie wiążą się z koniecznością ograniczenia tzw. niskiej emisji dymu, a to przekłada się m.in. na zmianę dotychczasowych sposobów użytkowania pieców węglowych przez wielu mieszkańców (zaprzestania spalania węgla niskiej jakości i różnego rodzaju toksycznych odpadów). Eliminowanie szkodliwych zachowań dokonuje się zwykle przez wprowadzanie coraz bardziej rygorystycznych regulacji prawnych i ściślejszy monitoring, a towarzyszą temu coraz większe koszty oraz sankcje; równolegle prowadzona jest kampania edukacyjna promująca pożądane wzory zachowań.

Rozwój miasta tworzą nie tylko zmiany waloryzowane pozytywnie, ale także negatywnie; rozwój ujmowany jest zarówno w kategoriach „postępu”, 
jak i „regresu” te dwa aspekty zazwyczaj współwystępują. Rozwój to nie tylko wprowadzanie do życia społecznego pożądanych wzorów zachowań, innowacji, poprawiających warunki życia szerokich kręgów społecznych, lecz także eliminowanie zjawisk negatywnych, dysfunkcjonalnych. Na rozwój składają się także zjawiska i procesy niepożądane, wręcz szkodliwe. Chociaż zakrawa to na paradoks, to nawet ,zbrodnia” może pełnić w społeczeństwie funkcje pozytywne wskazywał na to Emil Durkheim w swym klasycznym dziele [2000 s. 98-110]. Wyścig „miecza” i „tarczy”, tzn. sił konstruktywnych i destrukcyjnych, porządku i anarchii, przyczynia się do wprowadzania różnego typu innowacji i ciągłego przekształcania istniejących rozwiązań w różnych dziedzinach życia społecznego.

Analizując społeczne uwarunkowania rozwoju miast dosyć trudno uniknąć perspektywy modernizacyjnej, zakładającej cybernetyczny model sterowania zmianami. W ujęciu takim zakłada się pewien konsensus dotyczący pożądanego stanu celów rozwojowych, uprzywilejowaną perspektywę poznawczą ,podmiotu sterującego" (który utożsamiany jest zwykle z władzą), dysponowanie wiedzą ekspercką typu know how pozwalającą skutecznie implementować wypracowane rozwiązania modelowe. Takie ujęcia trzeba uznać za jednostronne, umniejszające znaczenie spontanicznej aktywności społecznej oraz nieuwzględniające w wystarczającym stopniu wielokierunkowego charakteru równoczesnych działań licznych podmiotów. Odrzucenie omnipotencji władz pozwala w większym stopniu uwzględnić aktywność innych podmiotów, w tym zwłaszcza aktywność obywatelską.

Rozwój miasta w znacznym stopniu uwarunkowany jest charakterem codziennych działań jego mieszkańców. Zachowania poszczególnych „aktorów” przekładają się na zjawiska i procesy masowe tworzące realne „fakty społeczne”. Szczególnie istotne są powtarzane regularnie wzory zachowań, gdyż one tworzą swoiste byty replikatywne, jakimi są instytucje, zwyczaje, obyczaje, rytuały, mody itp. Powtarzalność zachowań masowych nadaje życiu społecznemu miasta specyficzny rytm. Ten swoisty schematyzm życia społecznego jest zgodny z zasadą ekonomii wysiłku, gdyż raz wypracowanych rozwiązań nie trzeba wymyślać za każdym razem na nowo. W innym jednak wymiarze prowadzi do poczucia monotonii życia, co może skłaniać do zachowań eskapistycznych, irracjonalnych lub poszukiwania alternatywnych form życia. Zachowania kompensujące dominujące cechy życia w mieście stają się niejednokrotnie źródłem społecznych innowacji, modyfikujących funkcjonowanie sfery instytucjonalnej. Powstawanie różnego typu enklaw społecznych [Gołdyka i Machaj 2007, s. 9-10] sytuujących się poza głównym nurtem życia społecznego, pozwala niekiedy na wypracowanie alternatywnych propozycji rozwoju. Zinstytucjonalizowane formy społecznego eskapizmu, pomimo swego nonkonformistycznego charakteru, umożliwiają w dłuższej perspektywie intensyfikację procesów społecznych przeobrażeń. 


\section{Rozwój a zmiany w sferze normatywnej}

Na rozwój miast można spojrzeć przez pryzmat zmiany sposobów wartościowania uwidaczniających się w zachowaniach mieszkańców. Perspektywa ta w znacznym stopniu syntetyzuje różne sposoby ujmowania zmiany i rozwoju. U podstaw każdego działania społecznego dostrzec można procesy wartościowania, które przekładają się na wybór celów oraz instrumentów działania i pozwalają łączyć poszczególne czynności (akty) w szersze kompleksy działań.

Rozwój i zmiana społeczna wiąże się zazwyczaj z procesami przewartościowań. Wskazać można dwa aspekty tego procesu. Z jednej strony są to wynajdywane coraz to nowe sposoby realizacji uznawanych wartości, z drugiej strony wskazuje się nowe wartości-cele. Przewartościowania mogą przybierać różne formy, dlatego warto wskazać kilka ich typów, które najczęściej można zaobserwować, takich jak:

- obniżanie lub podwyższanie miejsca danej wartości w relacjach z pozostałymi wartościami,

- zmiana sieci powiazań między wartościami; od nieznacznych przesunięć do radykalnych przewartościowań; od zmian cząstkowych do zmian totalnych,

- ugruntowanie wartości - brak przesunięć w sferze wartości, ale pogłębienie stopnia internalizacji wartości; przejście od „zewnętrznego" i dosyć powierzchownego uznawania znaczenia danej wartości do jej głębszego odczuwania (internalizacji),

- zmiany kryteriów i zasad wartościowania - przejście od jednego względnie koherentnego systemu wartości do innego systemu opartego na innych zasadach.

Większość istotnych procesów społecznych zachodzących na obszarze miasta wywoływana jest przez działania masowe. Liczne jednostki, w sposób niezależny od siebie podejmują podobne decyzje, które prowadzą do zaistnienia pewnych zjawisk, ujmowanych jako fakty społeczne. Wiele tego typu procesów występuje równocześnie, w sposób niezależny od siebie. Niejednokrotnie wchodzą one z sobą w interakcje, potęgując efekty pożądane lub szkodliwe.

Oddziaływanie na zmianę wzorów zachowania dużych zbiorowości społecznych dokonuje się zazwyczaj przez różne formy edukacji oraz perswazji, a także przez wprowadzanie regulacji normatywnych. Zmiany tego typu można uznać za formę przewartościowania. Kształtowanie rzeczywistości społecznej za pomocą przepisów prawnych jest najczęściej stosowanym sposobem wywoływania zmian zachowań. Ten sposób działania widoczny jest na wielu poziomach życia zbiorowego - od poziomu państwa i struktur ponadnarodowych do poziomu firmy, administracji osiedla. W sferze relacji interpersonalnych różnego typu normy dotyczące zachowań przybierają formę obyczajów, zwyczajów, ustanawianych kodeksów zachowań i niepisanych reguł i kodów zachowań. Ten gąszcz różnego 
typu regulacji pełni, jak wskazują przedstawiciele nurtu neoinstytucjonalnego, wiele pozytywnych funkcji, umożliwiając przewidywanie zachowań innych podmiotów i ich wzajemną koordynację. Może jednak także przyczyniać się do ograniczania swobody zachowań, ich spontaniczności i generować poczucie ubezwłasnowolnienia. To spętanie przepisami tłumi inicjatywę, prowadzi niejednokrotnie do powstawania sytuacji uznawanych za absurdalne, stwarza niepotrzebne komplikacje w załatwianiu z pozoru prostych spraw. Nadmiar regulacji paraliżuje życie społeczne w jego różnych przejawach, rodząc niekiedy tendencje eskapistyczne.

Wiele problemów społecznych występujących w życiu miasta powstaje w następstwie szkodliwych zachowań mieszkańców. Eliminowanie lub zmiana takich zachowań nie zawsze dokonuje się łatwo, wymaga niejednokrotnie długiego czasu oraz intensywnych akcji informacyjnych. Ogólnie można stwierdzić, że najistotniejszym problemem jest ograniczanie skłonności do ,jazdy na gapę" zarówno pierwszego, jak i drugiego stopnia [Turner 2005, s. 362]. Przeciwdziałanie efektowi ,jazdy na gapę” wiąże się m.in. z możliwością kontroli zachowań członków danej społeczności. Rozwój technicznych możliwości stałego monitorowania stopnia natężenia różnorodnych procesów miejskich, kształtowanych przez ludzkie zachowania, w istotny sposób wpływa na pojawienie się nowej jakości życia miejskiego. $\mathrm{Z}$ jednej strony wpływa to na wzrost poczucia bezpieczeństwa mieszkańców i przeciwdziałanie występowania negatywnych zjawisk przez sterowanie żywiołowymi procesami, z drugiej prowadzi jednak do poczucia totalnej kontroli i możliwości ingerencji „władz” w sferę prywatności. Gromadzenie olbrzymiej ilości danych o codziennych zachowaniach obywateli stwarza nowe zagrożenia. Dane te mogą stać się podstawą różnego typu nadużyć, a w przypadku ich pozyskania przez grupy przestępcze działań ukierunkowanych wprost na zaszkodzenie konkretnym osobom. Także podatność na ataki hakerskie systemów sterowania procesami miejskimi stwarza możliwość celowego wywołania paraliżu miasta.

\section{Kompensacje miejskie}

Miasto jest środowiskiem sztucznie wytworzonym przez człowieka, co może wywoływać pewne specyficzne zachowania społeczne. Wiele z tych zachowań można traktować jako reakcje kompensacyjne zarówno na uciążliwości, jak i wygody życia w mieście. Mówiąc o reakcjach kompensacyjnych, chodzi tu o reakcje na dominujące cechy systemu społeczno-kulturowego. W tym przypadku dotyczy to specyficznych warunków życia w aglomeracjach miejskich. Pojęcie to różni się zatem w istotny sposób od ujęć z obszaru psychologii społecznej [Byrka, 
2015 s. 90 i nast.], gdzie odnoszone jest do wcześniejszych zachowań działającej jednostki. W proponowanym tu społecznym ujęciu kompensacji ten aspekt temporalny jest także zawarty. Trzeba również zwrócić uwagę, że reagowanie na cechy systemowe nie ma charakteru odruchowego, lecz jest dosyć złożonym procesem interpretatywnym, chociaż jego przebieg nie jest sobie przez jednostkę (grupę) w pełni uświadamiany.

Georg Simmel [1975] w swoim klasycznym studium na temat mentalności mieszkańców wielkich miast wskazywał dominujące cechy życia w mieście. W punkcie wyjścia podkreślał jednak, że „najbardziej istotne zagadnienia współczesnego życia wynikają z pragnienia jednostki, aby zachować niezależność i odrębność własnej egzystencji w obliczu przemożnego naporu społeczeństwa, dziedzictwa historycznego, zewnętrznej kultury i techniki życia”. Zaznaczał, że chodzi o „opór podmiotu wobec prób glajchszaltowania go i oddania na usługi mechanizmów społeczno-technicznych” [Simmel 1975, s. 513]. Dążenie jednostki do zachowania własnej autonomii i opór wobec różnego typu nacisków i oddziaływań płynących ze strony systemu społeczno-kulturowego uznać można za przejaw zachowań kompensacyjnych. $Z$ jednej strony jest to pewna reakcja obronna, z drugiej - przejaw własnego indywidualizmu.

Na podobne procesy zwracał uwagę Norbert Elias [2011, s. 495-512] w socjologii historycznej, gdy analizował przemianę rycerzy w dworzan. Ukazywał on rolę procesów pacyfikacji, czyli tłumienia impulsywnych zachowań w wyniku narzucenia przez państwo monopolu na stosowanie przemocy. Obecność procesów pacyfikacji dostrzec można także współcześnie w sposobie funkcjonowania wielu instytucji, począwszy od placówek edukacyjnych i wychowawczych, a na przedsiębiorstwach, korporacjach i rozmaitych stowarzyszeniach skończywszy. Odreagowanie tych oddziaływań następuje dosyć często w formie różnych zachowań irracjonalnych, destrukcyjnych (i autodestrukcyjnych). Znajdują one swój wyraz także w przestrzeni miejskiej w postaci aktów wandalizmu, celowego łamania norm, awantur i agresywnego zachowania jednostek oraz grup mieszkańców.

Wskazywany przez N. Eliasa proces przemiany rycerza w dworzanina można traktować jako dosyć trafny model dwóch tendencji, między którymi oscylują zachowania współczesnych mieszkańców miast. Z jednej strony są to zachowania charakterystyczne dla „dworzanina” przebiegające zgodnie z obowiązującymi normami i zasadami współżycia społecznego, zachowania pełne uprzejmości i kurtuazji, z drugiej strony są to zachowania charakterystyczne dla „rycerza”, będącego wojownikiem, dającym upust swoim instynktom, podejmującym śmiałe wyzwania, wymagające męstwa i odwagi. Te dwa typy zachowań występują często przemiennie u tej samej osoby, zależnie od kontekstu sytuacyjnego. W sytuacjach oficjalnych stosowany jest zwykle kod zachowań charakterystyczny dla „dworzanina", w sytuacjach innych, poza strukturami instytucjonalnymi z ich systemem 
kontroli społecznej, realizowany jest wzór zachowania charakterystyczny dla „rycerza”. Nawiązując do języka teorii gier, można powiedzieć, że jednostki stosują ,strategie mieszane”, wykorzystując oba kody zachowań. Poniekąd wbrew N. Eliasowi można utrzymywać, że model „rycerza” nie tyle został zastąpiony przez wzór „dworzanina”, ile, że oba te wzory zachowań utrzymują się równolegle i pojawiają się w różnych typach sytuacji. Maria Ossowska [1986] w swoim studium ethosu rycerskiego te dwa wymiary zintegrowała, wysuwając na plan pierwszy aktywność rycerza zmierzającą do obrony osób krzywdzonych, natomiast u N. Eliasa dominuje impulsywny charakter jego postępowania.

Życie codzienne w warunkach wysokiego poziomu natężenia regulacji normatywnych, a także stałych procesów nadzoru i kontroli zachowań wywołuje w człowieku procesy pacyfikacji, czyli tłumienia i wewnętrznej kontroli różnych reakcji emocjonalnych. Tego typu zachowania są oczekiwane i wzmacniane przez otoczenie społeczne oraz zinstytucjonalizowany system nagród i kar. Z tego względu przy różnych okazjach może dochodzić do bardziej lub mniej spontanicznych zachowań niezgodnych z narzucanym kanonem charakterystycznym dla modelu „dworzanina”. Zachowania te określane jako „irracjonalne” można traktować jako swoistą reakcję kompensującą procesy pacyfikacji. Formy tego odreagowania mogą przybierać charakter konstruktywny (społecznie aprobowany) lub destrukcyjny zarówno dla jednostki, jak i zbiorowości. Miasto, z racji dużej anonimowości występującej wśród mieszkańców oraz grupowej solidarności osób podejmujących destrukcyjne zachowania, pozwala na uniknięcie odpowiedzialności, co może z kolei rodzić poczucie bezkarności i zachęcać do powtarzania takich działań.

Dominujące cechy życia wielkomiejskiego - intensywne tempo życia i towarzyszący temu nieustanny pośpiech, duża ruchliwość, wysoka gęstość zaludnienia i wynikające stąd zatłoczenie w miejscach publicznych, anonimowość, przelotność i powierzchowność kontaktów społecznych, ,,samotność w tłumie”, hałas i duży ruch uliczny itd. - próbuje się w różny sposób kompensować. Z jednej strony, są to cykliczne „ucieczki” z miasta - wyjazdy wakacyjne i weekendowe, przenoszenie miejsca zamieszkania poza ruchliwe centrum na tereny podmiejskie lub do dzielnic „spokojniejszych”. Z drugiej strony w miastach tworzone są pewne enklawy ciszy i spokoju, przykładowo tereny zielone, obszary wyłączone z ruchu samochodów, osiedla grodzone.

Wiele zachowań irracjonalnych uznać można, jak już zaznaczono, za swoiste reakcje kompensacyjne na warunki życia w środowisku wielkomiejskim. Nie wdając się w próbę ścisłego zdefiniowania tej kategorii zachowań, można przyjąć, że zachowania irracjonalne są takim rodzajem działań, które przynoszą szkodę podmiotowi w sytuacji, gdy można łatwo przewidzieć te negatywne następstwa i nie są one podejmowane w imię zmiany ustanowionych zasad życia społecznego. 
Zachowania uznawane za irracjonalne mogą mieć charakter ciągły lub incydentalny. Do pierwszej grupy można zaliczyć wszelkie uzależnienia, a także systematyczne naruszanie jakichś norm społecznych, np. przestępczość i niektóre typy patologii społecznej. Do drugiej grupy można zaliczyć różnego typu pojedyncze ekscesy. Rozpowszechnienie się monitoringu miejskiego pozwala na pokazanie całej gamy irracjonalnych zachowań ludzkich, które, jak można przypuszczać, mają charakter incydentalny. Bardzo często są to zachowania podejmowane pod wpływem alkoholu lub są rezultatem specyficznego nastroju i emocji. Wskazać można przykłady takich zupełnie bezsensownych zachowań: demolowanie różnych elementów infrastruktury miejskiej, przystanków, ławek, reklam, niszczenie zieleni i kwiatów, niszczenie elewacji budynków (pseudograffiti). Do kategorii zachowań irracjonalnych zaliczyć też można awantury i różne formy agresji między jednostkami i grupami. Wszystkie te zachowania można traktować jako irracjonalne, nie tylko dlatego, że są zaprzeczeniem rozsądku, ale także dlatego, że są rezultatem emocji, mają więc charakter pozaracjonalny. Emocje te mogą być nieświadomym przejawem „odreagowywania” skumulowanych napięć oraz frustracji. W przypadku działań grupowych dołącza się do tego klimat emocjonalny wytworzony w następstwie interakcji między poszczególnymi osobami. Ten nastrój może sprzyjać procesom deindywidualizacji. Przekonanie o własnej bezkarności w warunkach braku kontroli (przekonanie, że „nikt nas nie widzi, bo nikogo nie ma") sprzyja podejmowaniu zachowań antyspołecznych. Zachowania te można traktować jako chwilowe oderwanie się od reguł narzucanych przez społeczeństwo, do których na co dzień jednostka zmuszona jest się stosować.

Społeczeństwo wypracowało pewne sposoby rozładowywania tego typu napięć i przeciwdziałania kumulowaniu się poczucia ubezwłasnowolnienia przez reguły życia zbiorowego oraz ukształtowane nierówności społeczne. W niektórych okresach dopuszcza się odwrócony porządek świata - jest to czas karnawału, zabawy, świętowania. Ulice miast stają się wówczas areną różnego typu zachowań znacznie odbiegających od codziennej rutyny, a niekiedy wręcz zbiorowego szaleństwa. Tego typu wydarzenia pełnią funkcje kompensacyjne; pozwalają zapomnieć o szarej rzeczywistości i na chwilę od niej się oderwać. Ta przysłowiowa „szara rzeczywistość" jest w znacznym stopniu efektem procesów replikatywnych w życiu społecznym, to znaczy iteracyjnego powtarzania wielu zachowań koniecznych do normalnego funkcjonowania społeczeństwa na jego wszystkich poziomach. Prowadzi to często do poczucia monotonii, które jest przezwyciężane przez uczestnictwo w różnych wydarzeniach kulturalno-rozrywkowych, sportowych lub przez poszukiwanie „mocnych wrażeń”. Podróżowanie staje się często okazją do „kolekcjonowania wrażeń” i jest ucieczką od monotonii codzienności. Władze wielu miast próbują w jakiś sposób skanalizować tendencje irracjonalne, będące rezultatem samorzutnych kompensacji, przez organizowanie różnego typu wyda- 
rzeń rozrywkowych, festynów, zabaw itp. Podobne funkcje pełnią wydarzenia sportowe, które stają się grupowym substytutem walki (a niekiedy wręcz wojny). Trzeba jeszcze zaznaczyć, że w warunkach turbulentnych zmian społecznych owa monotonna codzienność staje się stanem wysoce pożądanym, dając jednostce poczucie stabilizacji.

\section{Konkluzje}

Społeczna dynamika przekształceń miasta może być ujmowana w kategoriach rozwoju. Pojęcie to nie musi mieć charakteru wartościującego, ani wiązać się z perspektywą modernizacyjną. Rozwój miasta rozumiany jest tutaj jako ciąg wzajemnie ze sobą powiązanych zmian zachodzących w różnych sferach życia mieszkańców. Zachodzące zmiany mogą być różnie waloryzowane i ujmowane z odmiennych perspektyw poznawczych. Na wstępie przyjęto relacjonistyczny punkt widzenia, wskazując wzajemne interakcje między różnymi podmiotami aktywnymi na obszarze miasta, jako istotny element warunkujący przemiany zachodzące w tej sferze. Za szczególnie doniosły uznano związek występujący między zmianami społecznymi a zachowaniami mieszkańców. Większość zmian zachodzących na poziomie miasta znajduje swoje odzwierciedlenie w codziennej aktywności obywateli. Podobna zależność występuje w drugim kierunku - zachowania masowe mieszkańców kształtują przeobrażenia miasta. W tym kontekście stawiane jest pytanie dotyczące sposobów regulowania zachowań ludności miast. Najprostszym narzędziem pozwalającym kształtować zachowania dużych zbiorowości jest sfera regulacji normatywnych, a zwłaszcza przepisów prawnych w różnych przejawach. Istotne znaczenie posiada także kształtowanie świadomości, perswazja i edukacja. Regulacje normatywne narzucane są zazwyczaj przez władze administracyjne, ale także wyłaniają się w sposób spontaniczny w trakcie życia codziennego i potem są formalizowane. Trzeba wskazać, że nazbyt chętne posługiwanie się tym narzędziem prowadzi do przeregulowania sfery normatywnej, a także do inflacji oraz braku spójności obowiązujących przepisów. Normatywne regulowanie ludzkiej aktywności występuje także w sferze instytucjonalnej. W wymiarze zbiorowym prowadzi to do procesów pacyfikacji, wzmożonej kontroli zachowań na różnych poziomach i w konsekwencji tłumienia indywidualnej spontaniczności. Tego typu sytuacja prowadzi do zachowań kompensacyjnych. Przybierać one mogą różne formy; jedne z nich są społecznie aprobowane, inne są celowym naruszaniem ustanowionych norm lub mają charakter eskapistyczny. Wiele zachowań uznawanych za „irracjonalne” mieści się w tym nurcie. Rozwój miasta ujmowany z tej perspektywy polega na odchodzeniu od modelu biurokratycznego zarządzania w kierunku budowania 
klimatu kooperacji i troski o dobro wspólne. Wiąże się to ze zmianą sposobu kształtowania relacji społecznych.

\section{Literatura}

Amsterdamski S. [1983], Między historiq a metodq. Spory o racjonalność nauki, PIW, Warszawa.

Blumer H. [2007], Interakcjonizm symboliczny. Perspektywa i metoda, Zakład Wydawniczy Nomos, Kraków.

Bourdieu P. [2009], Rozum praktyczny. O teorii działania, Wydawnictwo Uniwersytetu Jagiellońskiego, Kraków.

Byrka K. [ 2015], Łańcuchowe zmiany zachowań w kontekście ochrony środowiska i promocji zdrowia, Wydawnictwo Naukowe PWN, Warszawa.

Durkheim É. [2000], Zasady metody socjologicznej, Wydawnictwo Naukowe PWN, Warszawa.

Elias N. [2011], O procesie cywilizacji. Analizy socjo- i psychogenetyczne, Wydawnictwo W.A.B., Warszawa.

Gerencser M., van Lee R., Napolitano F., Kelly Ch. [2008], Megacommunities. How Leaders of Government, Business and Non-profits can Tackle Today's Global Challenges Together, Palgrave Macmillan, New York.

Gołdyka L., Machaj I. [2007], Enklawa życia społecznego kategoriq pojęciowq socjologii. Prolegomena [w:] Enklawy życia społecznego, red. L. Gołdyka, I. Machaj, Wydawnictwo Naukowe Uniwersytetu Szczecińskiego, Szczecin.

Hart K., Padayachee V. [2011] Development [w:] The Human Economy. A Citizen's Guide, eds K. Hart, J.L. Laville, A.D. Cattani, Polity Press, Cambridge, Malden.

North D. [2006], Efektywność gospodarcza w czasie [w:] Wspótczesne teorie socjologiczne, t. 1, wybór i opracowanie A. Jasińska-Kania i in., Wydawnictwo Naukowe Scholar, Warszawa.

Orren K., Skowronek S. [2004], The Search for American Political Development, Cambridge University Press, Cambridge.

Ossowska M. [1986], Ethos rycerski i jego odmiany, PWN, Warszawa.

Park R.E. [1925], The City. Suggestion for the Investigation on Human Behavior in the Urban Environment [w:] The City, eds R. Park, R. Burgess, University of Chicago Press, Chicago.

Sagan I. [2000], Miasto scena konfliktów i wspótpracy. Rozwój miast w świetle koncepcji reżimu miejskiego, Wydawnictwo Uniwersytetu Gdańskiego, Gdańsk.

Simmel G. [1975], Socjologia, PWN, Warszawa.

Turner J. [2005], Struktura teorii socjologicznej, Wydawnictwo Naukowe PWN, Warszawa.

Znaniecki F. [1931], Miasto w świadomości jego obywateli, Polski Instytut Socjologiczny, Poznań. 


\section{Urban Development - the Social Dynamics of Transformation}

\section{(Abstract)}

In the paper urban development is understood as a chain of connected changes in the different spheres of inhabitants' lives. Changes in urban areas depend on interactions between different actors. Foremost is the connection between the everyday behaviour of people and social changes. Individual behaviours are shaped by normative regulations, while excessive regulations lead to pacification and compensational reactions. Social dynamics of the changes in urban areas depend in many cases on the relationship between pacification processes and compensation.

Keywords: urban development, mass behaviour, social change, pacification, compensation. 